\title{
LIX. Anatomical observations on the structure of the ornithorynchus paradoxus
}

\section{J.F. Blumenbach}

To cite this article: J.F. Blumenbach (1802) LIX. Anatomical observations on the structure of the ornithorynchus paradoxus, Philosophical Magazine Series 1, 11:44, 366-367, DOI: $10.1080 / 14786440208676008$

To link to this article: http://dx.doi.org/10.1080/14786440208676008

曲 Published online: 18 May 2009.

Submit your article to this journal $\sqsubset \pi$

Џ Article views: 2

Q View related articles $\sqsubset$ 


\section{[ 366 ]}

LIX. Anatomical Obfervations on the Siructure of the Ornithoryncbus Paradoxus. By J. F. Blumen Bach, Profefjor of Medicine at Göttingen, and Member of the Medical Society of Paris*.

$\mathrm{T}$

$\mathrm{HE}$ fpecimen of this animal in my poffeffion is about 19 inches in length; the head is 4 inches; the tail nearly the fame; and the neck and trunk 10 inches $\dagger$.

It is covered with two kinds of hair. The interior gray, fhort, and very foft, like down; that on the outfide, mixed with others longer and ftiffer, brownifh on the back, and yellowith on the belly.

The limbs are hort. The fore feet are about $2 \frac{1}{2}$ inches in length; the hind feet are fomewhat longer. The feet have five toes, palmated (natatorii). The natatory membranes of the fore feet are very broad, not inferted between the toes, but attached below them, fo as to be better calculated for diving.

The tail flat, and covered with ftiff hair like briftles.

But what appears moft fingular and anomalous is the conformation of the head, being furnifhed with a broad beak refembling that of a duck. The mandibles, fpatula-formed, are flat. The upper one, about 2 inches in length, and $\mathbf{I}_{3}^{\frac{1}{3}} \mathrm{~d}$ in breadth.

Thefe mandibles are covered with a coriaceous membrane, which extends to the corners of their aperture.

The under mandible, which is narrower than the upper, is ferrated (a, fig. 1. Plate IX.) on the edges, as is the cafe in a duck's bill. The palate is furrowed acrofs.

My fpecimen is deftitute of teeth, like that defcribed by Dr. Shaw; but I have lately been informed, in a letter from Sir Jofeph Banks, that in another fpecimen two fmall dentes molares have been found on each fide of each mandible.

The whole beak at the root is edged with an undulated membranaceous border running acrofs it $(b)$.

* From Mémoires de la Socièté Médiciale demulation, qualitíme annie.

+ Dr. Bobba, a very refpedtable phyfician now refident at Göttingen, had before fent us a very interefting note on the ortitborynchus parailoxis, in which he fays that there are three fpecimens in Great Britain timilar to that in the poffeffion of profeffor Blumenbach; viz. one in the Britilh Mufæum ; one in the poffeffion of Mr. Dobron, an amateur of natural hiftory at London; and a third in the univerfity of Edinburgh. But the information he fent us having been already publifhed in the Bulletin des Sciences, we did not think it neceffary to iniert it in this work. We have confined ourfelves therefore to thefe new obfcrvations of profeffor Blumenbach. - Note of tbe Frencb Editor. 
Philo.Mag. Pl. XX.Vol.XI.

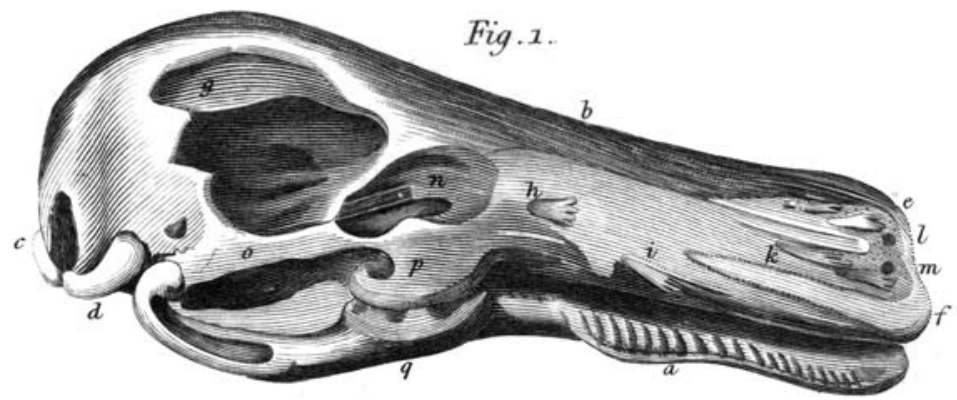

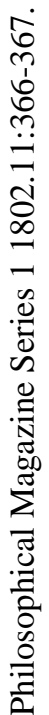

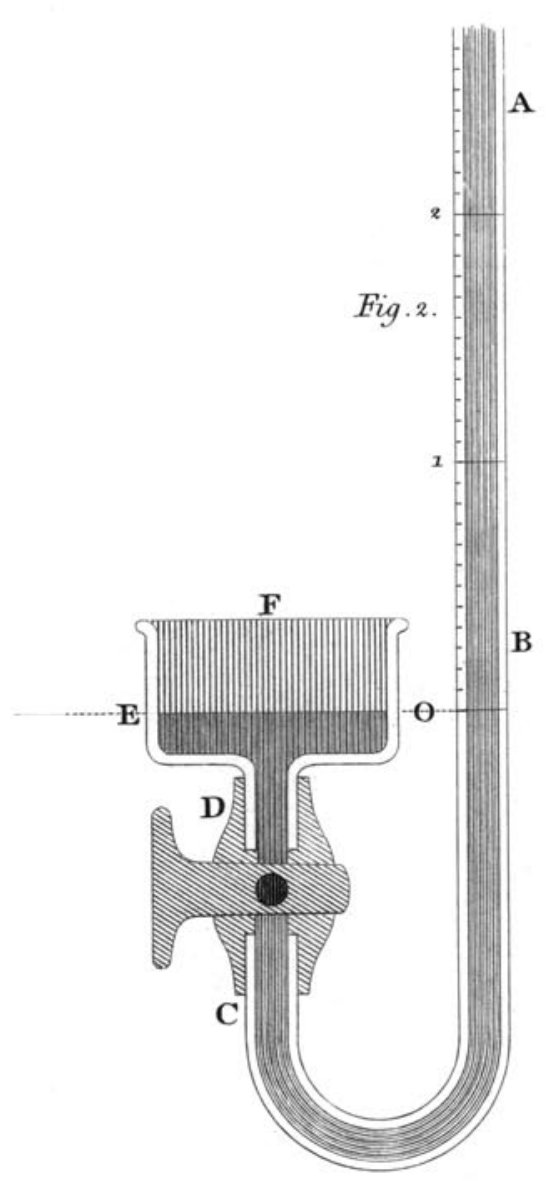

Lowry sailp. 
The conformation of the cranium, taks n from the occipital condyli $(c d)$, and the intermaxillary bones $(e f)$, has, on the firlt view, a great refemblance to that of the duck. The bones of the $1 \mathrm{kull}$ are divided by no futures; but the interior chamber of the brain is divided by an offeous hook $(g)$ running lengthwife, which is found in no other quadruped *, and fimilar to that of the teirao urogallus.

What feems to be highly worthy of notice, however, is the remarkable apparatus of the nerves of the fecond branch of the fifth pair, and the diftribution of it in three regions of the coriaccous membrane which furrounds the beak. The nerve $(b)$ which proceeds from the lower orbital foramen goes to the tranfverfe edge: the other (i), which iffues behind the intermaxillary bones, is diftributed on the labial edges: the third $(k)$, which iffues from the fynchondrofis, that divides the anterior hooked legs of the intermaxillary bones, proceeds to the integument of the beak.

Comparing this large apparatus of maxillary nerves, with which nature has provided this coriaceous integument, and the like ftructure of the duck's bill, there can fcarcely be a doubt that this highly ferifible membrane, which furrounds the beak, ferves, in a very particular manner, in the orritboryncbus, as in aquatic birds, for the purpofes of feeling, by means of which thefe animals can fearch for their food in muddy places, where neither fight nor fmell can be of any ufe to them in that refpect. Hence the eyes of the ornitboryncbos are very fmall, but the noftrils $(l m)$ exceedingly broad.

This wonderful animal, therefore, affords an exception to the order of the internal fenfes affigned to quadrupeds by Buffon $t$, who fays: "In quadrupeds, fmell is the firft of fenfes; tafte is the fecond; or rather, thefe two form only one: fight is the third; hearing the fourth; and feeling the laft."'

In the annexed figure, one of the bones of the fkull is reprefented broken, that the interior of the chamber of the brain may be feen. $N$, denotes the orbita; $O$, the zygoma; $\mathbf{P Q}$, the proceffus molares of each mandible. The other parts will be underftood from the preceding defcription.

* I once found, but the inftance is very rare, a fimilar ofieous hook in the cranium of a woman about thirty years of age.

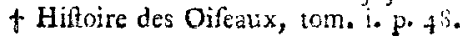

